\title{
Verden i følge Lars Engels
}

\author{
Af Ib Bondebjerg
}

\begin{abstract}
Artiklen er en nogtern presentation og analyse afflere af den danske tv-instruktor Lars Engels' tv-dokumentaristiske varker. Artiklen søger dels at tilbagevise den påstand, at Engels tv-varker er at regne for "socialpornografi", dels at argumentere for, at stilen og estetikken $i$ Engels arbejde peger $i$ retning af både nødvendigt og demokratisk tv. Forfatteren stiller sig med sin analyse meget positivt overfor Engels' tv-dokumentarisme, men fastholder samtidig, at det er nødvendigt at bevare en kritisk analytisk position, selv overfor en social og sympatisk tv-genre og tv-produktion.
\end{abstract}

Siden monopolbruddet i 1988 har den danske tvkultur oplevet et markant boom i dokumentariske udsendelser. Virkelighedsstof og faktuelt indhold har også udgjort kernematerialet i mange andre former, som er vokset kraftigt på tv-fladen. Et af de nye fænomener har været reality-tv (se Bondebjerg 1996 og 2000) - en iscenesat dokumentarisk form, som både har været at finde på de traditionelle public service kanaler og på de nye kommercielle kanaler. Men fokus i denne artikel ligger på den særlige form for dokumentarisme, som Lars Engels er den førende dokumentariske tv-repræsentant for, og som han har udviklet som medlem af DRDokumentargruppen, der har spillet en central rolle for den nyere danske tv-dokumentar.

DR-Dokumentargruppen fik fra 1988 exceptionelt frie arbejdsbetingelser og skabte gennem det tætte samarbejde mellem lydfolk, klippere, fotografer osv. en integreret dokumentarisk stil, som har sat sig afgørende spor i de to hovedspor inden for tv-dokumentarismen, som blev udviklet inden for DR, men også i et vist omfang inden for TV2 (se Bondebjerg 2000): På den ene side den dybdeborende, afslorende og magtkritiske dokumentar ("den hårde pakke") og på den anden side den observerende, sociale reportage ("den bløde pakke"). Det er formater, som har en lang forhistorie på tv, men som her efter monopolbruddet blev udviklet yderligere.

Ser vi helt generelt på de typiske retoriske og stilistiske elementer, som indgår i en dokumentarfilm, og som skaber de genremæssige grundtyper, kan man som John Corner (Corner, 1995, s. 85ff) sondre mellem i hvert fald 5 elementer: forklaring, interview, observation, dramatisering og iscenesattelse.
Den måde, disse grundelementer sammensættes på, bestemmer så igen, hvordan den pågældende dokumentariske form fordeler sig på de i hvert fald tre grundlæggende æstetiske prototyper inden for dokumentarismen, som Carl Plantinga har stillet op: den autoritative (formal), den åbne (open), den poetiske (poetic) (Plantinga, 1997 s. 101ff).

Den autoritative form er den klassisk oplysende dokumentarfilm, normalt med autoritativ voice-over, hvor der søges mod en sammenhængende logisk, kausal forklaring på et bestemt fænomen i den virkelige verden. Fremstillingen benytter virkemidler, der med ekspliciteret autoritet og tydelighed giver svar på de spørgsmål, teksten selv rejser. Der er altså $\mathrm{i}$ en vis forstand tale om en meget lukket retorisk struktur og om et ofte meget tydeligt forklarings-dokumentationsforhold mellem speak og billede. Samtidig bruges der ofte en række klassiske retoriske formler og kneb grænsende op til stærk propagandistisk brug af tale, lyd og billede.

Den åbne form er netop Lars Engels domæne, og den er karakteristisk ved at observere og udforske virkeligheden, snarere end at søge at forklare den. Her stilles ikke eksplicitte spørgsmål, og der gives ikke eksplicitte sammenfattende svar på bestemte spørgsmål. Af samme grund er denne æstetiske prototype ikke præget af klassisk retoriske eller narrative strukturer og indrammer ikke det fremstillede ved hjælp af autoritativ voice-over og brug af et bestemt dokumentationsforhold mellem tale og billede. Der tales som oftest fra et sted i den registrerede virkelighed og ikke om den. Fremstillingen er enkel og båret af en ikke målstyret og kausal tilrettelæggelse af virkeligheden, der giver 
en episodisk og registrerende struktur og en minimalistisk stil. Den åbne form har et fænomenologisk forhold til virkeligheden, dvs. den forsøger at forstå virkeligheden ved at gennemlyse dens umiddelbare, hverdagslige fænomener snarere end ved at forstå virkeligheden gennem abstrakte begreber og strukturer.

Endelig har vi den poetiske form, som er den æstetiske prototype, hvor dokumentarfilmen nærmer sig den mere avantgardistiske og eksperimenterende film, den lyrisk-associative virkelighedsbeskrivelse eller den parodierende og meta-tekstlige form. I Danmark er bl.a. Jon Bang Carlsen og Jørgen Leth repræsentanter for denne æstetiske form, men det er en form, som indtil for nylig har været relativt sjælden på tv. Den poetiske form bruger ofte på en meget bevidst måde iscenesættelse og vil være præget af en særlig prægnant og betydningsfuld brug af lyd- og billedeffekter, som styrer modtagerens opfattelse af den virkelighed, som her fremstår meget stilistisk bearbejdet.

\section{Under-Danmarks sociale talerør}

Lars Engels har, siden han blev færdig på Den Danske Filmskole i 1976, lavet mere end 30 dokumentarfilm og tv-dokumentarudsendelser. Fra starten med De gale i Havanna (1977) og til de foreløbigt sidste, tv-trilogien Dømt til behandling (DR-dokumentar, 1-3, 1997) og Historier fra en politistation (DR1, 1-13, 2001) er der en klar social og tematisk linje. Lars Engels laver portrætter af og skildrer hverdagen for de mere eller mindre udstødte dele af Under-Danmark: De sindslidende, de kriminelle, narkomanerne, de prostituerede og de sociale tabere. Han skildrer dem dels ved at komme tæt på dem som enkeltpersoner og typer, dels ved på enestående vis at formå at trænge ind i deres egen verden, deres eget miljø og kunne færdes på de institutioner og blandt de professionelle, som er sat til at tage hånd om dem.

Konsistensen i Engels tematik, sociale sigte og dokumentariske stil er forbløffende fra første film. Med sit portræt af et sindssygehospital i Havanna på Cuba lægger han sig fra starten i en cinema verité tradition, der viser den usminkede virkelighed, men også søger efter de menneskelige ressourcer hos de socialt og kulturelt udstødte. Samtidig lægges sider af samfundet og dets institutioner frem til offentlig beskuelse, og filmen overskrider på denne måde tabuiserede grænser mellem det private $\mathrm{og}$ det offentlige. I program-teksten fra SFC til filmen skriver Engels og Borker:

"Vi har ønsket at lave en film fra de gales lukkede og utilgængelige verden. Vise det liv, vi intet kendskab har til. Afmystificere hele den dystre stemning, som de sindssyge omgærdes med - for at finde frem til de gales eget udtryk, som er et andet sted end den overflade, man normalt præsenteres for. Desuden har det været vigtigt for os at holde fast i de sindssyges positive ressourcer og ikke kun i symptomerne på deres sygdom." (Lars Engels citeret efter Thygesen, 1991, s. 5).

Denne programerklæring kunne også stå over Dømt til behandling. Det er ikke svært at se sporene efter 70ernes anti-psykiatri-bølge ideologisk set, og heller ikke svært at se inspirationen fra den engelske instruktør Ken Loach og hans film Family Life (1972) med dens systemkritiske skildring af skizofreniens baggrund. Men særlig stærk er inspirationen - specielt hvad angår dokumentarisk stil og genre - fra amerikaneren Frederick Wiseman. Wiseman er den udenlandske instruktør, som mest konsekvent siden 1960erne har ladet det hverdagslige og institutionaliserede liv udfolde sig helt ukommenteret for vores øjne. Det gælder filmen Titicut Follies (1967), der var en af de første indforståede og kritiske skildringer af de kriminelt sindssyges verden og det amerikanske behandlingssystem. Filmen skabte en voldsom debat, bl.a. omkring hvor meget man kunne tillade sig at vise fra de syges verden - en debat, som i meget høj grad minder om debatten omkring Engels udsendelse Dømt til behandling ${ }^{1}$. Wiseman har siden lavet klassikere som High School (1968), en mosaikagtig skildring af livet på en amerikansk skole. Law and Order (1969), Hospital (1970) og Blind (1986 (se Barsam, 1992, s. 337-42), alle film som skildrer samfundsmæssige institutioner, som tager sig af samfundets tabere.

Som sit umiddelbare forbillede Wiseman lægger Engels ikke vægt på den systematiske kortlægning af en institutions struktur ved at søge at repræsentere alle dele af denne struktur på samme niveau. Han går først og fremmest direkte ind i institutionens umiddelbare dagligliv og lægger stærk og tydelig vægt på de enkelte individer i institutionen. Både hos Wiseman og Engels træder en række stærke og forskellige individuelle portrætter og typer frem, som tilsammen danner et mosaikagtigt sociologisk mønster. Ved samtidig at fokusere på 
sam- og modspillet mellem disse individer, fanget $i$ en socialt underlegen position og indlejret $i$ et system, som skal tage sig af dem, bliver det også et sociologisk studie i institutionelle og sociale processer i praksis. Men det er ikke et perspektiverende og forklaret sociologisk studie, selvom fremstillingen naturligvis er underlagt enkle selektions- og strukturerings-mekanismer, der rummer en grundlæggende holdning.

Der er tale om et flow af ikke-iscenesat hverdagsliv, som er organiseret i prægnante situationer og forløb, der tilsammen danner en helhed, en slice-of-life verden, som det i høj grad er op til modtageren at forholde sig til og fortolke. Lars Engels er den indlevende observatør og interviewer, men netop meget ofte fraværende, også som interviewer, og i næsten alle sine udsendelser går han helt bevidst uden om speak og autoritative kommentarer. Han bruger de medvirkendes egne statements som nøgle, og er, når det drejer sig om æstetiske virkemidler og retoriske greb, bevidst meget asketisk: En sjælden, men ofte prægnant brug af lyrisk-metaforiske billedpassager med musik, en vis dramaturgisk-narrativ opbygning og en meget bevidst dokumentarisk brug af normallys, reallyd og et levende, ofte håndholdt kamera og nærbilleder.

Det er ikke i Lars Engels udsendelser, man făr det perspektiverende, sociologiske og journalistisk analyserende. Han anskueliggør menneskelige og sociale problemer og miljøer, som de færreste aner eksistensen af, og som man i bedste fald kun har stereotype fordomme om. Hans dokumenter er rystende i synliggørelsen af en menneskelig elendighed, som man skulle forsværge fandtes i velfærdsstaten Danmark. Men det er ikke social pornografi og voyeurisme, det er snarere sociale stereotyper, der făr ansigt og menneskelig karakter og dermed gør det vanskeligere for det almindelige Danmark og myndighederne bare at reducere dem til anonyme, sociale tilfælde og til bureaukratiske sagsnumre. Men udsendelserne viser også de utrolige menneskelige ressourcer, det kræver, hvis det offentlige skal tackle de problemer, der vises frem. I næsten alle Engels udsendelser er det ofrene for systemet, taberne og de svage, der står i centrum, og som man identificerer sig med. Sådan er det også delvis i hans seneste serie Historier fra en politistation (2001). Men her er der dog klart en tydeligere synsvinkel via stationen og betjentene og deres arbejde som "samfundets skraldemænd". For første gang er distancen til de sociale ofre således set fra en mere institutionel synsvinkel og i meget høj grad via politiets optik (se Bondebjerg, 2002b).

Manglen på forklaringer og løsninger i Lars Engels udsendelser sætter for nogle spørgsmålstegn ved, om udsendelserne nytter noget og giver informationer, der kan udnyttes i den offentlige debat, eller om det bare får velfærdsdanskeren til at gyse og fă sine værste anelser bekræftet om det dernede og derude. På dette spørgsmål til Engels selv og til den observerende genre som sådan, har han selv svaret, idet han her markant tager afstand fra et journalistisk krav om at få det hele med og komme med forklaringer og løsningsperspektiver:

"Det synes jeg ikke, jeg er jo ikke journalist, jeg har gået på filmskolen (...) og har en anden indgang til stoffet. Jeg mener tværtimod, at jeg er med til at nedbryde fordomme. De her piger, som alle kun kender som skygger på gaden, eller de hjemløse, som vi bare ser hutle rundt, altså, som man jo aldrig ville gå hen $\mathrm{og}$ snakke med. Når vi så går $\mathrm{i}$ gang med dem, og snakker, og de begynder at udtrykke sig, så pludselig bliver de mennesker, og de făr menneskeværd, og man făr medlidenhed med dem, og man tænker "gud, hvordan går det dem" (...) Man får fordomme nedbrudt tror jeg, ved at vise det her, oven i købet er det jo sådan, at vi har meget fordomme om dem, vi ikke normalt ser. Det er meget sjældent, vi ser de rigtige mennesker, går ned i deres miljø, lader dem udtale sig, hvad synes de, og hvordan har de det. Det tror jeg der er et enormt behov for. Det er derfor man godt kan lide sådan nogle udsendelser (...) Næsten alle de folk vi ser, ingen af dem ville være kommet på skærmen, hvis jeg ikke lige præcis havde været der. Jeg ved ikke hvordan man journalistisk ellers skulle kunne formidle deres situation, det at være hjemløs, det at være psykisk syg osv. (...) Men hvis man har set en af de her film f.eks., så tror jeg, der er scener, der brænder sig fast, der er nogle ting, som man husker (...) det sidder lige der, fordi det gør sådan et indtryk på dem.” (Lars Engel interview-citeret efter Rasmus Dahl, 1994, s. 79).

Rollen som tv-mediets dokumentariske talerør for det sociale Under-Danmark har skaffet Lars Engels et stadigt voksende tv-publikum: Når der er Lars Engels på skærmen, så er vi ofte oppe at runde 1 million seere. Den observerende dokumentarisme har altså en fascinationskraft helt på linje med den nationale film- og tv-fiktion. Selv har Lars Engels da også talt om, at hans film, som til 
stadighed de senere år har kredset om Vesterbro, er hans form for Danmarksfilm, og han taler om dem som et korrektiv til den måde, virkeligheden på tv som oftest beskrives på. Det er det modsatte af den uendelige række af eksperter, politikere og studieværter, som ellers synes at sætte hinanden stævne på tv (Engels, 1993, s. 15).

Engels dokumentarudsendelser har desuden givet ham en række priser, men har også ført til voldsomme anklager for social pornografi fra antropologer og folk i det sociale system - angreb, der er blevet mødt af lige så stærke forsvar fra samme type mennesker (1). Bølgerne har gået højt, og udsendelserne har skabt offentlig debat. Selv har Engels peget på, at de personer og miljøer, han skildrer, aldrig har reageret negativt, og at der er taget etiske hensyn. Har medvirkende eller pårørende ønsket ting klippet fra, er det fulgt. Han peger endvidere på, at de portrætterede vender tilbage i flere udsendelser, og at han fra de lokale på Vesterbro modtager talrige forslag til nye emner, der bør tages op (Engels, 1993). Det tyder altså langtfra på voyeuristisk socialpornografi, men netop på at Engels udfylder en rolle som talerør for andre grupper, andre sociale virkeligheder, end dem vi oftest ser på tv. Der blev dog i forbindelse med Historier fra en politistation rejst alvorlig tvivl om, om alle de "medvirkende" havde givet samtykke til, at sekvenserne med dem måtte bruges, eller kunne overskue konsekvenserne af et tilsagn.

\section{Lars Engels og den observerende og åbne form}

"Det er karakteristisk for mine udsendelser, at der er lange passager, altså at jeg prøver at lade kameraet køre så længe som muligt, så få klip som overhovedet muligt. Det giver en fornemmelse af, synes jeg, at der ikke er manipuleret, vi er tæt på, altså vi glemmer næsten at kameraet var med (...) Det giver sådan en autenticitet, altså, så derfor kører jeg det i den stil. “ (Lars Engels, citeret efter interview i Rasmus Dahl, 1994, s. 55).

Udsagnet her fra 1994 kan stå som en slags æstetisk trosbekendelse for den observerende dokumentarisme, som Engels udnytter i mere og mere ren form i udviklingen af sine dokumentarudsendelser. Som i den klassiske cinema verité form går bestræbelsen i minimalistisk retning, dvs. mod så uredigeret en form som muligt og mod at lade de agerende og den fremstillede virkelighed tale for sig selv. Men en ting er forekomsten af relativt lange, uklippede sekvenser i løbet af udsendelsen, hvor vi får fornemmelsen af at være med selv, således som kameraet optog scenen og lyden, der hvor optagelsen fandt sted - noget andet er den samlede udsendelse. Alle dokumentarudsendelser må benytte sig af montage, dvs. sammensætningen af kortere eller længere enkeltsekvenser til udsendelsens faktiske forløb. Her foregår en selektion og en kombination, som i større eller mindre grad rummer en fortolkning af den registrerede og for så vidt autentiske virkelighed. Men ingen kan fange noget uberørt, og den uredigerede virkelighed ville være kedelig og usignifikant. Al kommunikation rummer altså redigering, selektion og valg.

Men Engels vælger en retorisk form og æstetisk stil, som bringer os tæt på en fænomenologisk, åben oplevelse af hverdagslivet og dettes flydende tidsflow, som ganske vist er konstrueret og redigeret, men alligevel følger et kronologisk flow meget tæt. Det sker mest radikalt i udsendelsen Natlager (1990), hvor vi følger to natlæger rundt på Vesterbro på besøg hos i alt otte forskellige patienter i løbet af en enkelt nat. Her er der slet ikke nogen ikke-diegetiske kommentarer eller interviews, hvor man hører eller ser instruktøren eller andre fra filmholdet. Samtidig er forholdet mellem den viste tid og den skildrede tid relativt tæt og kronologisk. Stilen er også radikalt gennemført i I lejligheden ved siden af (1991), hvor det er en række distriktssygeplejersker, vi følger på besøg hos psykisk syge i deres egne lejligheder. Men her er den tætte relation mellem det skildrede og det reelle tidsforløb mindre. Vi springer midt i udsendelsen to måneder frem. Men i begge disse puristiske, observerende dokumentariske udsendelser, der fremtræder som rapporter fra en kaotisk, flydende virkelighed, har Engels foretaget en række valg og dermed i hvert fald indirekte ladet en intention og holdning komme til udtryk ved den måde, programmerne er iscenesat og sammensat.

Vender vi nu tilbage til Corners mere funktionelle opdeling af de enkelte elementer inden for dokumentarismen, så var den første af disse Forklaring. Det er betegnelsen for de dele af en dokumentarisk form, hvor eksplicitte overordnede beskrivelser af eller kommentarer til det fænomen, udsendelsen handler om, fremføres af en eller flere autoriserede stemmer, eventuelt støttet af dokumenter, tekster, modeller eller andre 
typer af bevismateriale. Fra nyhedsudsendelser kender vi strukturen med delegering af autoritet fra udsendelsens ankerperson til reportere ude i marken, og vi kender brugen af ekspertinterviews, hvor dialogen mellem intervieweren og den interviewede også danner en slags lokal del af forklaringen. Forklaringer er, som allerede omtalt, meget sjældne i den type observerende, human interest orienterede form for dokumentarisme, som Engels repræsenterer. Til gengæld er den aldeles afgørende i de dybdeborende, afslørende dokumentariske udsendelser, hvor journalisten agerer som en detektiv på en sag og skal fremlægge beviser og argumenter, der tilsammen danner en overbevisende forklaring.

Engels fremsætter ikke forklaringer, men gengiver oplevelser, stemninger, erfaringsberetninger og udsagn. Alligevel rummer enkelte af hans udsendelser elementer fra den klassisk forklarende dokumentar. Det gælder fx udsendelsen om livstidsfangen og politimorderen Palle Sørensen Havnen er vor (1989). Her bruges i udstrakt grad overordnet speak og klassisk journalistisk interviewteknik, samtidig med at dokumenter, facts og ekspertudsagn styrer og indrammer den del af udsendelsen, hvor vi hører og ser Palle Sørensens egen historie og oplever ham i enkelte situationer. Udsendelsen er dog i sine observerende dele og i interviewene stærkt præget af, at der var forbud mod at filme Palle Sørensens ansigt.

Interview hører ofte tæt sammen med de forklarende elementer, i hvert fald i det omfang der bruges en journalistisk styret interview-teknik, hvor rækken af spørgsmål ledes af søgen efter en bestemt forklaring og årsagssammenhæng, som skal opklare en sag. I den klassisk forklarende dokumentarfilm inden for Grierson-traditionen var interview ganske vist ikke centralt i denne betydning, bl.a. som følge af datidens tunge udstyr og teknologiske begrænsninger. Her klarer man sig med overordnet speak og forklaring, mens de mere klassiske journalistiske former, som efterhånden dukker op, rendyrker denne interviewstil. Så at sige alle dokumentariske og journalistiske programmer er baseret på interviewet som metode til at klarlægge arten af den virkelighed, man vil beskrive. Man kan altså sige, at interviewet er et grundlæggende researchværktøj. Men der er stor forskel på måden interviewet bruges i selve udsendelsen. I den klassiske journalistiske form veksler man mellem vidner og eksperter, og interviewet kan strække sig fra forhørsagtige, aggressive former til mere eller mindre ind- og medfølende erfaringsinterview. Samtidig giver det en stor oplevelsesmæssig forskel for modtageren, om spørgsmålene og intervieweren fremstår i udsendelsen (og billedet) eller er skåret væk.

Lars Engels er konsekvent skåret væk i billedet i sine udsendelser, og hans spørgsmål er yderst sjældent med. Samtidig er hans interviewteknik helt præget af den indlevende, erfaringsorienterede stil. Vi får derved forstærket indtrykket af at overvære en autentisk, nærværende virkelighed, der udfolder sig tæt på det normale og på de portrætteredes betingelser. Den styring, der finder sted med spørgsmålene, eller ved den måde de forskellige interviewsekvenser er sat sammen på, virker således mere tilfældig og præget af virkeligheden end af en forhåndsindstilling og opfattelse hos instruktøren. Men det er ikke altid, Engels kan undvære sine egne spørgsmål eller lade virkeligheden udfolde sig som om, den var upåvirket af kameraets tilstedeværelse.

I en klassiker som Pigerne på Halmtorvet (1992) - en udsendelse som følger de prostituerede dels på deres værested Reden, dels i deres lejligheder og på gaden - høres Engels selv relativt ofte som interviewer. Men det sker aldrig i fx Natleger eller I lejligheden ved siden af. Når Engels træder ind som interviewer, har det at gøre med, at visse af hans udsendelser kommer tæt på den enkelte i situationer, hvor de er alene i isolerede omgivelser, og hvor der ofte er tale om personer, som ikke er vant til at tale meget. I den situation bliver en enetale for kold og utroværdig, modsat de andre udsendelser, hvor lægerne og distriktssygeplejerskerne udgør en slags interview-stand-ins, og hvor der optages interviews i mere kollektive samtale- og institutionssammenhænge. Lars Engels har selv kommenteret sin interview-stil på følgende måde:

"Natlager og I Lejligheden ved siden af, hvor jeg ikke er med, det synes jeg selv er de reneste udsendelser. De har en vis renhed i sig på den måde, at tingene sker, uden at jeg siger det. Det er klart (...) at de prostituerede, de er ikke alt for meget talende og ikke vant til at være på fjernsynet, derfor må jeg påtage mig den rolle at være interviewer også (...) Man kan også sige (..) at jeg hele tiden har situationer, hvor der er nogen, der taler sammen, vi overværer et eller andet (...) Jeg behøver ikke at spørge. Jeg sørger for, at vi er i situationer, hvor 
de siger de ting, som vi gerne vil have at vide for at forstå scenerne." (Engels citeret efter Rasmus Dahl, 1994, s. 62-63).

\section{Bearbejdningen af autenticiteten}

Observation rummer de dele af en dokumentarfilm, hvor modtageren bliver vidne til optagelser af en faktisk autentisk virkelighed - i hvert fald den udgave af en sådan autentisk virkelighed, som udspillede sig foran kameraet. Dokumentarisk optagelse og observation er i forskellig grad påvirket af selve optagelsessituationen. Nogle begivenheder kan optages fra en sådan position, at det, der optages, ikke er påvirket af det, eventuelt fordi optagelsessituationen er skjult, eller fordi der er tale om en offentlig hændelse, hvor kameraet ofte naturligt er til stede. Normalt vil kameraets tilstedeværelse dog uundgåeligt fremkalde "posering" eller "redigeret adfærd" hos de skildrede personer: den rå virkelighed kan aldrig helt fanges.

I Engels udsendelse Den Store Aktion (1994), der følger narkopatruljen på Vesterbro under arbejdet i kvarteret og specielt en storstilet tilrettelagt razzia mod bagmændene, overværer vi i lange passager kriminelle handler og begivenheder fra politiets skjulte observationsposter. Her ser vi altså the real thing. Men i de fleste af Engels udsendelser kommer vi utrolig tæt på den private sfære og ind hos personer, som ikke er vant til at blive optaget. Lars Engels styrke som observerende dokumentarist er generelt, at han formår at opnå en tillid, som gør, at han kan færdes i miljøer, hvor det er svært at blive accepteret udefra. Det lykkes ham derfor også generelt at fjerne indtrykket af skuespil i de observerende passager. Men i visse tilfælde oplever vi personerne træde ud af deres dagligdagsrolle: De henvender sig til kameraet direkte, eller de spiller aggressivt op over for deres sagsbehandlere for at markere deres utilfredshed, mens de ved, at kameraet er på. Det sker gentagne gange i fx Et glas vand til fohnny (1994), hvor vi er på et socialcenter og møder klienterne og socialrådgiverne i ofte voldsomme konfrontationssituationer.

Dramatisering forekommer uhyre sjældent hos Engels og kun en enkelt gang i form af helt bevidst, iscenesatte rekonstruktioner eller fiktionaliserede case-stories. Det sker i de tre film under fællestitlen Tre historier fra Sølager, som foregår på et behandlingshjem for 15-18-årige. Her er det, som i den DR-tradition Poul Trier Petersen har været den tydeligste repræsentant for (Bondebjerg, 1989; Harms Larsen, 1990), de faktiske personer, der spiller sig selv. Men det sker på basis af en fiktiv case-story, som kunne være autentisk, men altså er baseret på et gennemarbejdet manuskript. Men dramatisering kan jo også betragtes i løsere betydning som brug af dramaturgiske spændingselementer og visse narrative grundformler. Dramatisering inden for dokumentarismen består ikke mindst i, at instruktøren - selv i et meget registrerende, episodisk forløb - må skabe en vis kausal sammenhæng $\mathrm{i}$ tid, sted og handling. I sin optakt og indledning og $\mathrm{i}$ overgangene mellem de enkelte dele af forløbet må han tænke i dramaturgiske baner. Lars Engels siger ganske vist om sin research og sin forberedelse:

"Mine historier bygges så op på det, der sker, og en forventning om at der sker noget. Inde i hovedet har jeg et manuskript, som består af tusinde af forskellige historier, fordi det kan være, der er nogen, der er væk eller nogen, der ikke kommer osv. Men jeg filmer som regel det, der sker. Derfor bliver det så levende, der er ikke noget, der er arrangeret af nogen som helst slags (...) Historien laves på stedet.“ (Engels, citeret efter Rasmus Dahl, 1994, s. 60-61).

Men sprogbrugen røber jo, at han trods alt tænker i historier. Det er da også ganske klart, at selv den observerende, dokumentariske metode er nødt til at sikre et vist minimum af kontrol under optagelserne, således at elementære oplysninger om tid og sted fx bliver synlige for modtageren. Men i særlig grad er det naturligvis klipningen og montagen af de optagne sekvenser, der muliggør en vis dramaturgisk styring. Det gælder fx i tilrettelæggelsen de centrale optakts-, overgangs- og afslutningssekvenser. I Orkanens øje (1991) er det ikke tilfældigt, at udsendelsen - der foregår i dagene op til jul - udnytter julens symbolværdi ved at starte og slutte $i$ det fælles julearrangement.

I indledningen starter vi med titlen hen over et kort af området, dernæst fokuseres på en sanger, der synger "Velkommen grønne adventskrans", mens kameraet panorerer henover de forsamlede i Mændenes hjem med kaffe og julebag. Mens sangen fastholdes og langsomt fades ned til fordel for reallyd udefra klippes der dernæst til et natligt/ tidligt morgenbillede i luftperspektiv af København-Vesterbro, der er ved at vågne, og vi går 
derfra direkte til vækningen i hjemmet. Altså en både karakteriserende, symbolsk og forankrende indledning. I slutningen følger vi optakten til det fælles julearrangement, hvor de kommer fra nær og fjern, og hvor selve slutsekvenserne med variation repeterer kamerabevægelserne fra begyndelsen. På lydsiden hører vi "Dejlig er jorden”, mens kameraet panorerer henover den fyldte spisesal, og derfra gås igen tilbage til fugleperspektivet af det natlige København. Julens budskab om fællesskab og menneskelighed benyttes her som metaforisk farvning af udsendelsen.

I Natleger benyttes de samme natsorte indlednings- og afslutningsbilleder af bydelen - denne gang ledsaget af blid Mozart klaverkoncert - men set fra taxaen, der transporterer lægen rundt, mens Pigerne på Halmtorvet tilsætter de samme typer billeder helt sin egen stemning. Det sker gennem udnyttelsen af en slags indledende lyrisk, establishing shot, hvor Halmtorvets miljø og prostitutionstrafik ses mod et stort trompe l'oeil murmaleri af en portal, der synes at føre ud mod den forjættende natur og frihed. Men forløbet ender på et frontalbillede af "Reden" - de prostitueredes eneste fristed, hvor mænd er forment adgang. Symbolikken er bastant, men berettiget på baggrund af de stærke skæbner der ses, og symbolikken understreges af underlægningsmusikken, Sinead O'Connors kærlighedsballade "Nothing compares to you." Forholdet mellem den solgte og den ægte kærlighed vibrerer under udsendelsen. Brugen af musik er i det hele taget ofte en slags ledetråd. I I lejligheden ved siden af sker det på en særlig måde, ved at start og slut er viet en af beboerne, som forgæves forsøger at spille et sammenhængende stykke på klaveret: Et billede på den psykiske verden, vi er på vej ind i, hvor normaliteten er gået i stykker.

Der er altså dramaturgiske, narrative elementer i den måde, Engels lader os komme ind og ud af sine meget virkelighedsnære udsendelser på. Men der er jo ikke tale om den sædvanlige optakt med præsentation af problem eller konflikt, som så styrer resten af forløbet frem mod en afklaring, således som vi kender det fra den forklarende dokumentariske type eller det klassiske, narrative forløb. Forløbet forbliver åbent og antydende i både start og slutning. Når Engels taler om historier i sine udsendelser, så er det altså en anden type historier, nemlig den type af historier, som udvikler sig ud af en række små sekvenser, som antyder en persons livshistorie, men hvis fragmenterede karakter net- op får os til tænke selv over den sammenhæng og det forløb, som ikke udfoldes eller forklares for os.

Engels bruger ind imellem tematisk begrundede eller kontrastbegrundede krydsklip, som vi kender det fra en traditionel fiktionsfilm. I Natleger følger vi fx ikke slavisk lægen først på det ene besøg og så på det andet. Vi klipper ind imellem fra den ene læge på besøg hos én type patient, tilbage til den anden læge på besøg hos en anden, og vi klipper mellem centralen og lægebilen. Ud af det meget omfattende materiale med i alt 22 sygebesøg (jvf. Engels, 1993, s. 14) kommer et forløb med otte, organiseret i et vist, tilrettelagt forløb, som făr os til at sammenligne og kombinere de forskellige små handlingsforløb på tværs, men som også skaber et forløb fra kl. 21-03 om natten, markeret ved lyset og urene i fremstillingen.

\section{Vesterbro on my mind: Den poetiske dimension}

Begrebet dramatisering er i det ovenstående blevet berørt på en måde, som også delvis grænser op til det sidste af Corners elementer mise-en-scene, som peger mod den tekniske-stilistiske del af en af dokumentarismens elementer. Hvor den profilmiske verden, som danner baggrund for fiktionsfilmen, helt igennem er en konstrueret verden, selvom den godt kan foregå i realistiske kulisser og på autentiske steder, er den profilmiske verden i dokumentarismen i en eller anden forstand den virkelige verden. Vores forventning til dokumentarismen - selvom den tilhører den poetiske type, der er meget stærkt præget af stilistisk-æstetisk bearbejdning - er, at den er en påstand om verden, som vi direkte kan diskutere med eller forholde os til, mens fiktionsfilmen er en simuleret verden og historie, som dermed mere metaforisk udtaler sig om virkeligheden (Bondebjerg, 1994, s. 71f; Plantinga, 1997, s. 7ff; Branigan, 1992, s. 193f). Men det betyder jo ikke, at man i dokumentarismen bare filmer derude og derudaf: Valget af lys, optageomstændigheder, kameravinkel, billedkomposition, lyd (både reallyd og underlægningsmusik), klipning osv. er udtryk for valg, der har direkte konsekvenser for den måde, tilskueren bearbejdes på perceptorisk, kognitivt og emotionelt (Plantinga, 1997, s. 147).

Selvom Engels fremstår som den ekstremt minimalistiske dokumentarist med sin konsekvent lavmælte, observerende stil, så er udviklingen af dette udtryk i sig selv et poetisk-æstetisk valg. Han 
lægger også, som vi har set i eksemplerne fra udsendelsernes indledning og slutning, en subjektiv poetisk-symbolsk toning ind på strategiske steder i sine udsendelser. Det ligger naturligvis også i Engels dokumentariske intention at vise den mange gange brutale, fysisk forfaldne og beskidte, nedværdigende, kropsligt forfærdende menneskelige tilværelse, som hans personer i 'yndlings-landsbyen' Vesterbro lever i. Udsendelserne dokumenterer det, så man næsten kan lugte og føle den virkelighed, der skildres. Men det er - som allerede programerklæringen til De gale i Havanna viste - også de håb, bristede drømme og muligvis forspildte menneskelige ressourcer, der trækkes frem. Det er 'Vesterbro on our mind', Vesterbro som symbolsk sindbillede, der træder frem, når den poetiske tone skrues på i udsendelserne.

Et klart valg i Engels måde at iscenesætte sin autenticitet på er lyssætningen. I udsendelserne om Vesterbro og generelt i hans senere udsendelser bruges der naturlige lyskilder, hvilket skaber en oplevelse af særlig stærk intimitet og autenticitet. Det skarpe lys indendørs er ofte forbundet med fiktionens lyssætning eller med tv-nyhedsrummets studievirkelighed, mens det lys, som fx dominerer i Natleger, netop er de delvist oplyste rum og ansigter fra lamper i lejlighederne eller fra nattens gadebelysning og billygter.

Som del af den poetiske dimension i Engels udsendelser indgår, som allerede omtalt, også musikken og brugen af særlige billedvinkler og billedtyper. De ofte panoramiske billeder i hans start og slut af udsendelser giver ikke bare et overblik, som bringer os på afstand af de konkrete skæbner, vi har mødt, men de er også stemningsbilleder. På samme måde forholder det sig med brugen af fx spejlet i Pigerne på Halmtorvet: Det er på én gang et konkret spejl, som pigerne kigger i, men spejlet signalerer også en drøm om at se godt ud, en drøm om en anden form for tilværelse, der udtrykkes ved, at man lægger makeup. Det er på én gang kynisk set forberedelsen til luderarbejdet, men det er også der, hvor man ser sig selv i øjnene. Musikken er endelig også en faktor i skabelsen af den poetiske dimension, som ofte præger Engels programmer, ikke ofte brugt, men når det sker til gengæld med stor effekt. Som allerede påpeget har brugen af et murmaleri og en sang af Sinead O'Connor en meget stærk symbolsk og poetiske effekt i Pigerne på Halmtorvet. Kombinationen af de to diskrete poetiske markører skaber hele den melan- kolsk-drømmende dimension i udsendelsen - en melankolsk-drømmende dimension, som handler om drømmen om at komme ud og væk, at få et andet liv. Det er en poetisk-symbolsk dimension, som kunne stå over mange af Engels udsendelser, som en art motto for alle hans personer. De er fanget $\mathrm{i}$ en livsform, et sygdomsbillede eller en social situation, som ikke rummer store muligheder for udvikling og frigørelse.

\section{Den dokumentariske tv-serie}

Lars Engels har igennem sine enkeltudsendelser ofte kredset om de samme miljøer og temaer, og i den forstand kan hans produktion siden 1988 i virkeligheden indirekte opfattes som en art tv-serie fra livet på bunden på Vesterbro. Men siden 1996 er han i stigende grad begyndt at arbejde direkte med længere og længere serier fra det samme miljø. Det giver større mulighed for at opbygge længere spændings- og fortællingskurver, og det rummer selvfølgelig også større mulighed for mere dybtgående og detaljeret at trænge ind i og afspejle miljøet, dets individer, netværk og institutioner. Første gang Engels skaber en dokumentarisk serie er i Piger $i$ Vestre Fengsel $(1-3,1996)$, som på sæt og vis kan ses som en fortsættelse af udsendelsen Pigerne på Halmtorvet. Hans seneste og også længste serie er Historier fra en politistation (DR1, 1-13, 2001) - en gigantisk kraftpræstation, hvor vi følger et meget stort persongalleri via deres møde med den lokale politistation (se Bondebjerg, 2002b). I det følgende skal Engels og hans dokumentariske serieproduktion imidlertid kort belyses og karakteriseres ud fra udsendelsen Dømt til behandling.

Den tre timer lange dokumentarudsendelse Domt til behandling blev sendt i april 1997 i tre dele: "Så er festen slut", "Min mormor var polsk prinsesse" og "In the Ghetto". Udsendelserne skildrer psykisk syge, mandlige kriminelle, der er blevet anbragt på den lukkede afdeling på Sct. Hans. Titlerne er citater fra de indsatte selv, i det sidste tilfælde dog via et citat fra en Elvis Presley sang, men titlerne angiver meget godt udsendelsens princip: Vi kommer meget tæt på de enkelte og får et stærkt indblik i deres delvis skøre og rablende måde at tænke og tale på, men også glimt af en skjult kreativitet og længsel efter et andet liv. Kameraet bevæger sig søgende og levende ud og ind af værelserne, opholdsstuerne og de ansattes kontorer, og vi følger dagligdagens forskellige ruti- 
ner og de til tider voldsomme sammenstød mellem de indsatte indbyrdes og mellem de indsatte og behandlingssystemet.

Forløbet af de tre udsendelser er sådan, at de to første udsendelser bygger på 12 personhistorier, fordelt med seks på hver af udsendelserne. I den første udsendelse møder vi den voldtægtsdømte Henrik, den skizofrene Flemming, der er dømt for at have slået sin arbejdsgiver ned, den tidligere ingeniør Eyvind, Jimmy med penisattrapperne, som hele tiden vil stikke af, Stig, som er på vej ud i friheden, Henry, der er defineret som psykopat, og som har myrdet sin egen mor, og vi ser i glimt en fremmedarbejder. Ikke alle personer er lige meget i centrum. Det er Henrik, der giver afsnittet titlen, og i denne første udsendelse står hans 'magtkamp' med lægen Boris og hans forsøg på at nedtrappe sit narkotikamisbrug (det er det, der kaldes festen), så han kan få udgangstilladelse, i centrum. Men også Jimmy, som er bæltefikseret og meget uklar i lange passager, fylder godt og illustrerer, sammen med Henriks historie, trangen til friheden - den helt basale længsel på en lukket afdeling. Den tredje hovedperson i første del er Flemming, der illustrerer det storhedsvanvid, den syge fantasiverden som også trives, og som fremsiges, så det næsten virker normalt. Der er tale om vildtvoksende skizofreni hos en person, der hører stemmer og ser sig som et uægte kongebarn.

I den anden af udsendelserne rykker seks andre personer ind på scenen. Der er den sorte Jeff, der også har et rigt fantasiliv bag den bamsede, bedøvede facade, og som giver afsnittet sin titel. Han ser sig som et uretfærdigt behandlet adelsbarn, men er samtidig fuld af musik, rytme, dans og rap-lyrik, der røber et stort, men uudnyttet menneskeligt potentiale. Der er den lidt enfoldige bankrøver Emil, hvis mor skjult forsyner ham med stoffer, og som går amok, da den trafik lukkes. Der er den meget aggressive Johnny, som mener, de andre er syge. Der er den evnesvage og fredelige Anton, der er dybt optaget af teknik og musik. Der er den grønlandsk-danske Pierre, der har lavet noget alvorligt snavs i Albertslund, som han ikke vil tale om, og som er omgivet af billeder af vilde dyr og fortæller stolt om sin grønlandske del af familien, der var rigtige storfangere. Og i slutningen af del to ser vi endnu en Johnny, skizofren og røveridømt, men med en vist talent for at tale og fortælle historier.

I den tredje og sidste del er det denne Johnny, hvis historie rykker mest i centrum. Han illustre- rer, at der bag det lidt tumpede ydre kan gemme sig en filosofisk og musikinteresserede person, der citerer de store filosoffer for lægerne og spiller "luftorgel" til sine plader. Men vi møder også den bæltefikserede Torben og Karl Johan, som er den, der forsyner afsnittet med titel. Hans oplæsning af Elvis-sangen "In the Ghetto" forsyner hele udsendelsen med en slags lyrisk slogan: Det er dem fra ghettoen, der bliver de "vrede unge mænd". Også Karl Johan rummer kreative dimensioner, han er optaget af at male det, som han selv kalder syrede billeder. Men ellers er tredje afsnit karakteristisk ved, at vi ikke møder så mange nye personer. I stedet samles der op og rundes af.

Som en anden fiktiv tv-serie med et stort kollektivt persongalleri er denne dokumentariske historie altså opbygget af cirka 15 minihistorier, som vi krydsklipper imellem. I det væsentlige er de enkelte sekvenser bygget op på samtaler, vi overværer mellem patienterne eller mellem patienterne og behandlerne. Men Engels er hele vejen igennem også ganske meget til stede som interviewer, således at vi får den nødvendige baggrundsviden om personerne på tomandshånd.

Formmæssigt er stilen minimalistisk. Klip mellem dage er markeret med sorte huller og følges ofte op af morgenritualet med pilleuddeling - et montageprincip, som naturligvis også peger måske lidt kritisk mod den meget stærke tvangsmedicinering, som foregår. Netop på grund af den minimalistiske stil bliver de få brud signifikante. Hele serien starter med, at vi kommer udefra og ind i bygningen, og det første, vi hører, er Ejvinds gudsjammerligt falske og usammenhængende klaverspil. Vi har set denne metafor på det syge sind og dets skjulte kreative reserver før, nemlig i indledningen og slutningen af $I$ lejligheden ved siden af. Derfor er slutbilledet på tredje afsnit også påfaldende: Her er det Emil, der trakterer et barnligt lille keyboard, der spiller forprogrammerede børnesange. Det er denne lyd, der slutter udsendelsen, samtidig med at vi ser slutteksterne hen over en stor, efterårsfarvet eg uden for vinduerne. Det virker som en metaforisk, indirekte kommentar: Hvad er det, vi gør ved disse tvangsbehandlede mennesker, en umyndiggørelse og infantilisering: Kunne vi gøre det anderledes?

Også enkelte andre gange bliver den visuelle stil påfaldende: Fx da kameraet under Flemmings historie i første del, hvor han benægter sin skizofreni, fokuserer på hans skygge (H.C. Andersen!), eller i den solidariske kameratur, der foretages i anden del 
rundt i den grønlandske Pierres lille fængsel, mens han stolt viser sine billeder af vilde dyr frem. Også i Lars Engels minimalistiske stil stikker, som tidligere omtalt, en poetisk-lyrisk billedmager (måske influeret af fotografen Lars Schou). Dokumentarisme, selv i den mest observerende form, er tilrettelagt. Men Lars Engels tilrettelægger med stor etisk fornemmelse og indsigt en virkelighed, som ligger uden for de flestes normale og daglige horisont.

\section{Den nødvendige og demokratiske tv-dokumentarisme}

"I mine øjne er udsendelser som 'Dømt til behandling' slet og ret socialpornografisk tv, der er karakteriseret ved at de udstiller socialt marginaliserede personer i nogle situationer, der almindeligvis betragtes som hørende til de mest intime og private $\mathrm{i}$ et menneskes liv (...) der er tale om en slags klassechauvinistisk underholdnings-tv, der stimulerer seernes voyeuristiske trang (...)" (Max Pedersen, 1997).

Således skrev antropologen Max Pedersen i en kronik, som var ét langt angreb på Engels og den observerende dokumentarisme, og som også pegede på, at der i det mindste ikke bare burde laves den slags tv om de sociale tabere, men også om "middelog overklassens livsførelse". Man kunne forstå angrebet, hvis den form for dokumentarisme, Engels bedriver, og de emner han tager op, var de eneste inden for dansk dokumentarisme. Den observerende tv-dokumentarisme i den meget rene form, som Lars Engels dyrker den, kan ikke stå alene. Og tematisk bør der naturligvis laves dokumentarisme om alle livsformer i Danmark. Men det sker faktisk også, så sandt som Lise Roos fx. de senere år har skildret et bredt udsnit af danske livsformer, hvor hun mange gange er kommet ganske tæt på det private også hos middel- og overklassen². Og det bør jo også huskes, at den mere dybdeborende journalistik ofte har fat i magteliten og den nålestribede livsforms ikke altid særligt flatterende bagsider.

Synsvinklen er derfor film- og mediehistorisk ganske skæv og helt unfair over for Lars Engels, som laver nødvendigt og demokratisk tv. Han viser sider af virkeligheden, som ofte er omfattet af kun statistisk eller tilfældig viden eller udokumenterede fordomme, og han giver mennesker og livsformer et sted at ytre sig i en medieverden, som ellers ofte er lukket for dem. Jeg ved ikke, hvordan man ellers skulle fremstille disse mennesker end ved så nænsomt og etisk som mulig at vise den måde, de faktisk lever på, og lade i det mindste glimt af menneskelige ressourcer og selvindsigt komme frem midt i den brutale virkelighed. Samtidig bliver hans udsendelser i tv og den øvrige dagspresse ofte udgangspunktet for en perspektiverende debat om de lukkede afdelingers behandlingsform, politiets arbejdsmåde eller vilkårene $\mathrm{i}$ det hele taget for de mennesker, som lever på samfundets bund. Men ved siden af denne evne til at skabe debat, så er Engels udsendelser først og fremmest karakteristiske ved, at de lader os andre, som lever på samfundets solside, opleve med egne øjne, at de mennesker på skyggesiden altså også er mennesker $\mathrm{og}$ har ressourcer og sider, som ikke har fået lov til at udfolde sig. De sociale tabere skildres både realistisk og medfølende hos Engels, men uden at det ender i social romantik eller social pornografi.

Engels er som dokumentarist med til at videreføre og udvikle en lang tradition for observerende dokumentarisme, der både har tidlige rødder i dansk tv og i den internationale tradition - en tradition, som går tilbage til 1960ernes amerikanske direct cinema. Som artiklen her har vist, så er det en form, som ikke har sin styrke i det forklarende og perspektiverende, således som det ses i den kritisk, dybdeborende journalistik. Til gengæld har den sin styrke i brugen af interview og observerende optagelser, der synliggør og giver stemme til de, som ofte ikke har et talerør i offentligheden. I alle sine udsendelser bruger Engels en yderst minimalistisk stil som altså til den ene side afgrænser hans udsendelser og hans æstetik fra den autoritative, dybdeborende dokumentar, og til den anden side til den poetiske eller iscenesatte dokumentar. Hvor den autoritative form benytter sig af forklaring og interview, men i en yderst direkte, retorisk struktur, der heller ikke går af vejen for at benytte dramaturgiske kneb og virkemidler, lægger Engels sig på den observerende akse med en interviewform, som må betegnes som indlevende og ikke konfronterende. Samtidig lægger Engels ganske vist sommetider poetisk-symbolske dimensioner ind i sine udsendelse fx i form af påfaldende billed- eller musikbrug, men hans stil er lagt fra den egentlig poetiske tradition i dansk dokumentarisme, hvor dramatisering og iscenesættelse gør selv udsigelsen til et meget centralt element i fremstillingen.

Engels minimalistisk, observerende stil er li- 
gefrem proportional med de alvorlige sociale og psykiske livsskæbner, han har gjort til sit tema. Men inden for den minimalistiske stil sætter han samtidig sit tydelige adelsmærke: Hans udsendelser har en tydelig æstetisk form og er ikke bare neutrale, observerende billeder. Han er talerør for det ukendte Under-Danmark og en nødvendig, social stemme i et stadig mere kommercialiseret faktabillede, hvor den ægte dokumentarisme er under pres fra den omsiggribende tendens i retning af reality-tv.

\section{Litteratur}

Barsam, Richard (1992). Non-Fiction Film. A Critical History. Bloomington: Indiana University Press.

Birkvad, Søren (1997). Livet i Danmark. Dokumentarfilmen. I Bondebjerg, m.fl. (red.). Dansk Film 1972-1997. København: Munksgaard-Rosinante.

Bondebjerg, Ib (1989). Opbruddet fra Monopolkulturen. Sekvens.

Bondebjerg, Ib (1990). Den sociologiske og visuelle lyd. Om radioen og radiomontagen i efterkrigstidens mediekultur. Mediekultur, 14.

Bondebjerg, Ib (1994). Narratives of reality. Documentary Film and Television in a Cognitive and Pragmatic Perspective. Nordicom Review, no. 1, 1994.

Bondebjerg, Ib (1996). Public discourse/private fascination: hybridization in 'true-life-story' genres. Media, Culture ES Society, vol.18, no.1.

Bondebjerg, Ib (1997). Between War and Welfare: Danish Documentary film in the 1950's. Aura, vol. II, nr. 3.

Bondebjerg, Ib (2000). I dialog med den danske virkelighed. I Hanne Bruun, m.fl. (red.), Tv2 på skermen. København: Samfundslitteratur.

Bondebjerg, Ib (2001). Den medialiserede virkelighed. Ekko, 8

Bondebjerg, Ib (2002). The Mediation of Everyday Life: Genre, Discourse and Spectacle in reality-Tv. In Anne Jerslev (red.), Realism and 'Reality' in Film and Media. Northern Lights. Film and Media Studies Yearbook, 2002.

Bondebjerg, Ib (2002a). Det sociale og det poetiske blik. Den nye danske dokumentarfilm. I Kosmorama, 229

Bondebjerg, Ib (2002b). Med politiet i virkeligheden. Reality-tv og kriminalitet. Mediekultur, 34.

Bondebjerg, Ib (2003). The social and the subjective look: documentaries and reflexive modernity. (MODINET Working Papers, 2003, www.modinet.dk).

Corner, John (1995). Television Form and Public Address. London: Edward Arnold.

Corner, John (1996). The Art of Record. Manchester: Manchester University Press.

Fritze, Helle \& Olsen, Mimi (1989). I faktionsmontagens spor. Sekvens, 1989.

Dahl, Rasmus (1994). Den visuelle dokumentarismes tekster.
Københavns Universitet: Specialebiblioteket (Upubliceret).

Engels, Lars (1993). 5 tv-dokumentarfilm om Vesterbro. Klip, nr. 19.

Harms Larsen, Peter (1990). Faktion - som udtryksmiddel. København: Forlaget Amanda.

Kjørup, Søren (1992). Faktion - en farlig blanding. Mediekultur, nr. 19.

Movin, Lars (1997): Den filmæstetiske avantgarde. Fra eksperimentalfilm til videokunst. I Ib Bondebjerg, m.fl. (red), Dansk Film 1972-1997. København: MunksgaardRosinante.

Pedersen, Max (1997. Oktober 5.). Socialpornografi. Politiken, kronik.

Plantinga, Carl (1997). Rhetoric and Representation in Non-Fiction Film. Cambridge: Cambridge University Press.

Thygesen, Erik (1991). Lars Engel's verden. Klip, 13.

\section{Lars Engels filmografi}

De Gale i Havanna (SFC, 1977, sm.m. Merete Borker)

Morten Maler (1981)

Sindslidelser (1981)

- $\quad$ Skt. Hans i maj

- $\quad$ Tre dage på lukket afdeling

Et kontor i to etager (1983)

Fangselsbilleder (1984)

En uge på Vridslose

Uro på B3

Øje for Oje

Rapport fra Helsingor Politistation (B\&U, 1985)

En ung mand på 20

Voldens Ansigt

Pigen med rotten

Tre historier fra Solager (1985)

- Kenneths anden verden

Hjem til Herlev

Retssagen

Fangersamfundet Scoresbysund (1987)

- Du er som en lille blomst

- $\quad$ Stilhedens àd

Rapport fra et kernekraftvark (1987)

$20 \mathrm{~km}$ fra Kobenhavn

Skiftehold 1 på Barsebäck

Anden i flasken

Narko bag tremmer (TV-Kulturafdelingen, 1988)

Heonen er vor (TV-Fakta, 1989)

Natlager (DR-Feature, TV-Fakta, 1990)

Orkanens øje (DR-Feature, TV-Fakta, 1991)

I Lejligheden ved siden af (DR-Feature, TV-Fakta, 1991)

Klaus Rifbjergs verden (DR, 1991, sm.m. Bente Hansen)

Pigerne på Halmtorvet (TV-Fakta, DR-Dok, 1992)

Alle disse Dage (TV-Fakta, DR-Dok, 1993)

Den store aktion (TV-Fakta, DR-Dok, 1994)

Et glas vand til fohnny (TV-Fakta, DR-Dok, 1994)

Havregrod til Egon (TV-Fakta, DR-Dok, 1995)

Piger $i$ Vestre Fengsel. 1-3 (TV-Fakta, DR-Dok, 1996)

Domt til behandling. 1-3 (TV-Fakta, DR-Dok, 1997)

Historier fra en politistation (DR1, 1-13, 2001) 


\section{Noter}

1 Den seneste debat om Lars Engels og den observerende dokumentarismes måde at beskrive den sociale virkelighed på brød ud i forlængelse af, at DR sendte de tre udsendelser under titlen Dømt til behandling i april 1997. En positiv artikel kom på dagen for den sidste udsendelse (Hans Jørgen Møller: Det nødvendige Fjernsyn. Politiken, 23/4, 1997), der lod Engels programerklæring komme til orde under rubrikken "Mennesker bag statistikkernes tal". Den 10/5 kom imidlertid antropologen Max Pedersens meget kritiske kronik (Max Pedersen: Socialpornografi, Politiken, 10/5, 1997). Kritikken blev fulgt op af amtsborgmester Per Kaalund (Ekstrabladet, 14/5 1997) og socialrådgiver Arne Nielsen, som på debatsiden i Politiken (20/5 1997) lagde sig op ad Max Pedersen. Samme dag forsvarede Jens Ravn Olsen, tilknyttet Mændenes Hjem, som dannede baggrund for udsendelsen Orkanens øje, imidlertid Engels - en linje, som blev fulgt af fængselsinspektør Ole Hansen, som havde været involveret som institutionskontakt i en række af Engels fængselsudsendelser. Redaktør Mads Baastrup fra DR-Dokumentar pegede i sin kommentar (Politiken, 21/5 1997) på udsendelserne som en nødvendig demokratisk åbning over for dem dernede og pegede på de etiske procedurer Engels fulgte i forhold til sine medvirkende - et tema, Engels selv tog op i sit indlæg (Politiken, 14/6 1997).

2 Der tænkes især på serier som Familien Danmark (1-3, 1994), Frikvarteret (1-4, 1995) og Fik du set det du ville? (1-4, 1997). Udsendelserne blev alle sendt på TV 2, og de gør Lise Roos til en af de helt centrale observerende realister i dansk tv ved siden af Lars Engels.

Ib Bondebjerg er professor ved afdeling for Filmog Medievidenskab ved Københavns Universitet, Institut for Medier, Erkendelse og Formidling. 